\title{
Discrimination of Meat Species in Processed Meat Products Based on the Ratio of Histidine Dipeptides
}

\author{
Hiroki $\mathrm{ABE}^{*}$ and Emiko OKUMA* \\ * Department of Food Science and Nutrition, Kyoritsu Women's University, \\ 1-710 Motohachioji, Hachioji, Tokyo 193
}

\begin{abstract}
Meat species discrimination was examined on heat processed meat products by the analysis of histidine dipeptides, carnosine, anserine, and balenine, using high-performance liquid chromatography. The distribution of these dipeptides and their ratios, carnosine/anserine and balenine/anserine, were specific to each meat species of beef, pork, horse, deer, chicken, and turkey. Products made from single meat species of beef, pork, or chicken were almost always correctly identified from the dipeptide ratios. This discrimination technique was unaffected by the contents of moisture, fat, and/ or other ingredients. The meat proportion in most of the mixed meat products made from any two meat species of beef, pork, and chicken was able to be semi-quantitatively determined using the standard curves of dipeptide ratio versus meat proportion.
\end{abstract}

Many investigations have been carried out to develop the analytical method for the discrimination of meat species of fresh meat and in processed meat products. Several methods such as protein electrophoreses, immunoassays, and profile analyses of certain proteins have been known to be valuable for the determination of fresh meat species ${ }^{12)}$. For processed meat products, however, most of the methods are not applicable because of the denaturation of muscle proteins during the curing and heat processing of raw meat. Therefore, for the discrimination of meat species in heat-processed meat products, it is necessary to use species specific and heat stable components such as heat stable proteins ${ }^{13) 4}$ ), fatty acids or fat species ${ }^{1)}$ ) and histidine dipeptides $^{1 \text { 5) }}$ or to use DNA hybridization ${ }^{6) \sim 8)}$ or polymerase chain reaction ${ }^{9)}$ methods.

Of these methods for processed meat products, histidine dipeptides: i.e., carnosine $(\beta$ alanyl-L-histidine), anserine ( $\beta$-alanyl-1-methyl-L-histidine), and balenine (ophidine ; $\beta$-alanyl-3-methyl-L-histidine), were first used by TINBERGEN and SLUMP ${ }^{10}$ for the detection of chicken meat in heated pork product. CARNEGIE et $a l^{11) \sim 13)}$ later confirmed the applicability of this method to various meat products.
More recently, PlowmAN and CLosE ${ }^{14)}$ also suggested the possibility of this method for the identification of meat species used in processed meat products. We have already reported a simple, sensitive, and time-saving determination method of these dipeptides using ion-exchange high-performance liquid chromatography (HPLC) ${ }^{15)}$ Thus, we intended to apply the method to meat species discrimination in processed meat products.

In this paper, we describe the distribution of histidine dipeptides in meat, meat species discrimination in processed meat products made from one meat species, and the semi-quantitative discrimination in those made from two meat species.

\section{Materials and Methods}

\section{Materials}

Horse and Japanese deer meats were obtained from local suppliers in Aomori and Iwate Prefecture, respectively. The other fresh meats were purchased from a wholesale food market in Hachioji (Tokyo). Samples of commercially available processed meat products were randomly purchased at supermarkets, groceries, and fast food shops in Tokyo and Los Angeles. 
Preparation of meat extract

After hand-trimming of the visible fat or removal of other ingredients from meats or meat products, about $50 \mathrm{~g}$ of the sample was minced using a meat grinder and mixed well in a mortar. From the sample, a $1 \mathrm{~g}$ portion was homogenized with $7 \mathrm{ml}$ of $8 \%$ perchloric acid using a Polytron homogenizer (Kinematica, Zurich). After centrifugation at $20000 \times \mathrm{g}$ for $15 \mathrm{~min}$ at $0^{\circ} \mathrm{C}, 5$ to $20 \mu l$ of the supernatant was injected into the HPLC.

\section{Determination of histidine dipeptides}

Histidine dipeptides were determined using a previously described HPLC method ${ }^{15)}$ with some modifications. Separation was carried out on a Shimadzu LC-6A liquid chromatograph equipped with a column $\left({ }^{\phi} 4.6 \times 250 \mathrm{~mm}\right)$ packed with Nucleosil-5 SA cation exchange resin (Macherey-Nagel, Duren). Elution was isocratic using $80 \mathrm{mM}$ potassium phosphate, pH 5.1 , containing $10 \%$ methanol at $55^{\circ} \mathrm{C}$ and at a flow rate of $1 \mathrm{ml} / \mathrm{min}$. Dipeptides were monitored at UV $210 \mathrm{~nm}$ with $0.01-0.04$ absorbance units at full scale.

Standard curves for calculating meat propor-

tions in mixed meat samples

After two meat species from minced beef, pork, and chicken were mixed in various proportions (10\% interval) in a mortar, meat balls weighing about $3 \mathrm{~g}$ were made and heated for $1 \mathrm{~min}$ in an oven preheated at $200^{\circ} \mathrm{C}$.
Dipeptides were extracted from the cooked meat balls and determined as previously described. For every combination, beef-pork, pork-chicken, and beef-chicken, experiments were repeated 8 to 16 times. Standard curves of histidine dipeptide ratios versus meat proportions were obtained from the average and standard deviations of the carnosine/anserine and balenine/anserine ratios for every meat proportion.

\section{Results and Discussion}

Distribution of histidine dipeptides in meats The concentration of histidine dipeptides and their ratios were determined in raw beef, pork, horse, deer, chicken, and turkey (Table 1). The distribution of these dipeptides was species specific in these meats. Variation between different beef (individual variation) was small as seen in the small standard deviations. This was also the case with pork and chicken. Our early results on various muscle portions of beef and pork suggested the small differences in the dipeptide contents (unpublished data). No large sample variation of histidine dipeptides was also found in deer. The sample variation, however, was large in horse and two bird species. Horse meat contained the highest carnosine level which was in the range of 26.3 to $57.1 \mu \mathrm{mol} / \mathrm{g}$ in leg muscles. In case of birds, the data were divided into two typically

Table 1 The content and the ratios of histidine dipeptides in meat

\begin{tabular}{|c|c|c|c|c|c|c|c|}
\hline \multirow{2}{*}{ Meat/Muscle } & \multirow{2}{*}{$\begin{array}{l}\text { Sample } \\
\text { No. }\end{array}$} & \multicolumn{4}{|c|}{ Contents $(\mu \mathrm{mol} / \mathrm{g}$ wet $\mathrm{wt})}$. & \multicolumn{2}{|c|}{ Dipeptide ratio } \\
\hline & & Car & & & Bal & Car/Ans & Bal/Ans \\
\hline Beef/leg & $5^{* 1}$ & $26.1 \pm 3.7$ & 5.94 & \pm 1.75 & $0.103 \pm 0.026$ & $4.79 \pm 1.48$ & $0.018 \pm 0.005$ \\
\hline Pork/leg & $6^{* 1}$ & $29.5 \pm 9.6$ & 1.42 & \pm 0.29 & $1.77 \pm 0.71$ & $20.5 \pm 3.4$ & $1.20 \pm 0.27$ \\
\hline Horse/leg & $3^{* 2}$ & $42.6 \pm 12.6$ & 0.17 & $6 \pm 0.030$ & $0.019 \pm 0.004$ & $260 \pm 111$ & $0.107 \pm 0.009$ \\
\hline Deer/leg & $5^{* 2}$ & $3.35 \pm 0.68$ & 13.9 & \pm 1.93 & $3.91 \pm 0.74$ & $0.253 \pm 0.080$ & $0.281 \pm 0.021$ \\
\hline Chicken/leg & $3^{* 1}$ & $5.7 \pm 1.7$ & 17.1 & \pm 3.7 & $0.055 \pm 0.028$ & $0.33 \pm 0.03$ & $0.003 \pm 0.001$ \\
\hline /breast & $4^{* 1}$ & $10.4 \pm 1.3$ & 32.0 & \pm 1.4 & $0.197 \pm 0.031$ & $0.33 \pm 0.04$ & $0.003 \pm 0.001$ \\
\hline Turkey/leg & $3^{* 2}$ & $4.53 \pm 0.68$ & 20.5 & \pm 1.9 & $0.077 \pm 0.009$ & $0.22 \pm 0.03$ & $0.004 \pm 0.001$ \\
\hline /breast & $2^{* 2}$ & $11.2 \pm 1.3$ & 46.0 & \pm 0.8 & $0.810 \pm 0.023$ & $0.24 \pm 0.02$ & $0.018 \pm 0.004$ \\
\hline
\end{tabular}

Mean \pm SD.

${ }^{-1}$ Average from the same muscle from different animals.

" Average from different muscles of one animal.

Abbreviations : Car, carnosine ; Ans, anserine ; Bal, balenine. 
different muscles, the leg and breast muscles (Table 1). They clearly differed from each other in dipeptide contents. These differences, however, were eliminated when the ratios of carnosine /anserine and balenine/anserine were compared as seen in Table 1. These results were almost identical to those previously reported ${ }^{12) 14}$.

CARNEGIE et al. ${ }^{11)}$ proposed the ratio of carnosine/anserine for the estimation of meat species in processed meat products. Table 2 shows the ranges of the ratios in all meats examined in the present experiment. The carnosine/anserine ratio appeared to be highly specific in each meat. Although the ratio of carnosine/anserine was almost the same in deer and turkey, the balenine/anserine ratio was distinctly different between the two species. The balenine/anserine ratio was a very small value and similar between chicken and turkey, but the carnosine/anserine ratio was different between these birds. Based on our preliminary experiment, the carnosine/anserine and balenine/anserine ratios in lamb meat were found to be 1.6 and 0.01 , respectively, which were also different from those found in the other species shown in Table 2 (unpublidhed data). These ratios were almost similar to those previously reported ${ }^{12) 14}$ ). Thus, these ratios may be independent of individuals of one animal species, muscle portions of an animal, and of water or fat contents. These data indicate that the raw meat species can be correctly discriminated from these ratios. Preliminary experiments revealed that these dipeptides were stable during post-

Table 2 Ranges of the ratios of histidine dipeptides in meat

\begin{tabular}{lcl}
\hline \multicolumn{1}{r}{ Meat } & Car/Ans & \multicolumn{1}{c}{ Bal/Ans } \\
\hline Beef & $4-15$ & $0.012-0.068$ \\
Pork & $16-26$ & $0.83-2.1$ \\
Horse & $102-394$ & $0-0.21$ \\
Deer & $0.13-0.35$ & $0.25-0.31$ \\
Chicken & $0.28-0.81$ & $0.005-0.015$ \\
Turkey & $0.18-0.27$ & $0.003-0.022$ \\
\hline
\end{tabular}

mortem conditioning at $4^{\circ} \mathrm{C}$ for 2 weeks, low temperature storage at $1^{\circ} \mathrm{C}$ for 9 days after conditioning, and heating for $5 \mathrm{~h}$ at $120^{\circ} \mathrm{C}$ (unpublished data). The contents of these dipeptides shown in Table 1 were not changed at all after cooking for $1 \mathrm{~min}$ at $200^{\circ} \mathrm{C}$. CARNEGIE et al. ${ }^{12)}{ }^{14)}$ also reported that heating beef and pork for $30 \mathrm{~min}$ at $180^{\circ} \mathrm{C}$ produced no loss of these dipeptides.

Meat species discrimination in processed meat products made from one meat species

Table 3 shows the contents and ratios of histidine dipeptides in various commercially available meat products made from one meat species. These data were obtained from three separate extracts from one product. The dipeptide content significantly differed among the products, which may reflect the difference in the moisture and fat contents and/or other ingredients of each product. The ratios of these dipeptides, however, were almost consistent with the ratios of each meat (Tables 1 and 2). This indicates that the ingredients other than meat will have almost no effects on the ratios. Thus, the determination of moisture content as described by the other workers ${ }^{12)(4)}$ can be omitted in the present method.

In the meat products shown in Table 3, lachsschinken (No.7), for instance, showed a rather high carnosine/anserine ratio compared with the pork value. This reason was unclear, but the product was estimated to be made from pork muscle judging from the balenine/anserine value. Canned sausage (No. 11) and frozen meat ball (No. 15) which were labeled as only pork showed rather low ratios compared with the pork value. These ratios were rather similar to those of the pork products mixed with chicken (Table 4). Thus, these samples were considered to contain other meat such as chicken or non-skeletal muscle of pork such as heart muscle which contains only trace amounts of these dipeptides ${ }^{12}$. All the other samples were correctly identified to be made from corresponding meat specified on the label. From these data, it is apparent that these meat species are easily discriminated in the processed meat products, if they are made from only one 
Table 3 Histidine dipeptide contents and the ratios in various processed meat products made from single meat species

\begin{tabular}{|c|c|c|c|c|c|c|c|}
\hline \multirow{3}{*}{$\begin{array}{c}\text { No. } \\
\text { Ham }\end{array}$} & \multirow{3}{*}{$\begin{array}{c}\text { Meat } \\
\text { products }\end{array}$} & \multirow{3}{*}{$\begin{array}{c}\text { Raw materials } \\
\text { labeled }\end{array}$} & \multicolumn{3}{|c|}{ Contents $(\mu \mathrm{mol} / \mathrm{g}$ wet $\mathrm{wt})}$. & \multirow{2}{*}{\multicolumn{2}{|c|}{ Dipeptide ratio }} \\
\hline & & & Car & Ans & Bal & & \\
\hline & & & & & & & \\
\hline 1. & Beef ham & beef & 14.3 & 3.03 & 0.094 & 4.7 & 0.03 \\
\hline 2. & Pork ham A & pork inside ham & 10.0 & 0.445 & 1.43 & 23 & 3.2 \\
\hline 3. & B & pork & 9.42 & 0.618 & 1.05 & 15 & 1.7 \\
\hline 4. & Boneless ham & pork inside ham & 14.5 & 0.792 & 1.29 & 18 & 1.6 \\
\hline 5. & Chicken ham $\mathrm{A}$ & chicken & 3.39 & 7.38 & 0.038 & 0.46 & 0.005 \\
\hline 6. & $\mathrm{~B}$ & chicken & 8.54 & 21.5 & 0.143 & 0.40 & 0.007 \\
\hline 7. & Lachsschinken A & pork loin & 24.4 & 0.616 & 1.08 & 40 & 1.8 \\
\hline 8. & B & pork loin & 26.3 & 1.35 & 2.94 & 19 & 2.2 \\
\hline \multicolumn{8}{|c|}{ Sausage } \\
\hline & Frankfurter & beef & 5.63 & 0.728 & 0.049 & 7.7 & 0.067 \\
\hline \multicolumn{8}{|c|}{ Canned products } \\
\hline 10. & Corned beef & beef & 2.05 & 0.368 & 0.010 & 5.6 & 0.027 \\
\hline 11. & Sausage & pork & 4.20 & 1.06 & 0.18 & 4.0 & 0.17 \\
\hline 12. & Meat paste & chicken & 3.62 & 8.49 & 0.046 & 0.43 & 0.005 \\
\hline \multicolumn{8}{|c|}{ Dried products } \\
\hline 13. & Beef jerky A & beef & 48.5 & 8.95 & 0.397 & 5.4 & 0.044 \\
\hline 14. & B & beef & 50.6 & 9.85 & 0.328 & 5.1 & 0.033 \\
\hline \multicolumn{8}{|c|}{ Frozen products } \\
\hline 15. & Meat ball & pork & 0.820 & 0.110 & 0.087 & 7.5 & 0.79 \\
\hline 16. & Chicken nugget & chicken & 4.94 & 13.7 & 0.084 & 0.36 & 0.006 \\
\hline \multicolumn{8}{|c|}{ Hamburger patty } \\
\hline 17. & Brand A & beef & 9.27 & 1.34 & 0.063 & 6.9 & 0.047 \\
\hline 18. & B & beef & 5.81 & 1.03 & 0.030 & 5.6 & 0.029 \\
\hline 19. & C & beef & 8.91 & 1.18 & 0.063 & 7.6 & 0.053 \\
\hline 20. & D & - & 7.29 & 1.11 & 0.044 & 6.6 & 0.040 \\
\hline
\end{tabular}

meat species.

Semi-quantitative discrimination of meat species in mixed meat products made from two meat species

Carnegie $e t a l{ }^{12)}$ previously tried to estimate the pork proportion in a mixture with other meat species such as beef, mutton, and chicken meat. Using the dipeptide ratios of each meat species, they made theoretical curves for the dipeptide ratios versus pork proportions and determined the pork proportion in several meat products. If a calibration curve including standard deviations is constructed from known mixtures of any two meat species, it may be possible to semi-quantitatively deter- mine the proportion of a given meat in a meat product made from two meat species.

Figure 1 represents the standard curves for cooked meat mixtures from any two combinations of beef, pork, and chicken meat. These curves were in good agreement with the theoretical ones calculated from the dipeptide ratios for each meat shown in Table 1. As the curve was rather hyperbolic for the pork and chicken mixture, both dipeptide ratios would give a broad range for the chicken proportion if the chicken proportion was above $50 \%$. This was also the case for the beef and chicken mixture. For the carnosine/anserine ratio of 1.0 in beef and chicken mixture, for instance, 
chicken proportion was estimated to be $25-70 \%$ based on the standard curve in Fig. 1 because of the relatively large standard deviations. Thus, the estimation was considered to be semi-quantitative as has been previously stressed $^{12)}$.

Table 4 shows the estimation of the chicken proportion in several commercially available meat products which were labeled pork and chicken. These products largely differed in their dipeptide contents, which showed the difference in the contents of moisture, fat, and/ or other ingredients. In the dipeptide ratios, however, the variations were eliminated and all the values fell into the range between pork and chicken (Table 1). From the ratios and the standard curves shown in Fig. 1, the chicken proportion was able to be estimated as shown in the parentheses in Table 4. The proportions estimated from the carnosine/anserine and balenine/anserine ratios were in good agreement in all samples. The range of the chicken proportion was rather broad in Chinese shao-mai (No. 7) in which the meat content was considered to be low from the depeptide contents.

The beef proportion in the various meat products labeled pork and beef was estimated (Table 5). These products differed in dipeptide contents as was seen in the other products (Tables 3 and 4). Beef proportions obtained from each dipeptide ratio, however, were
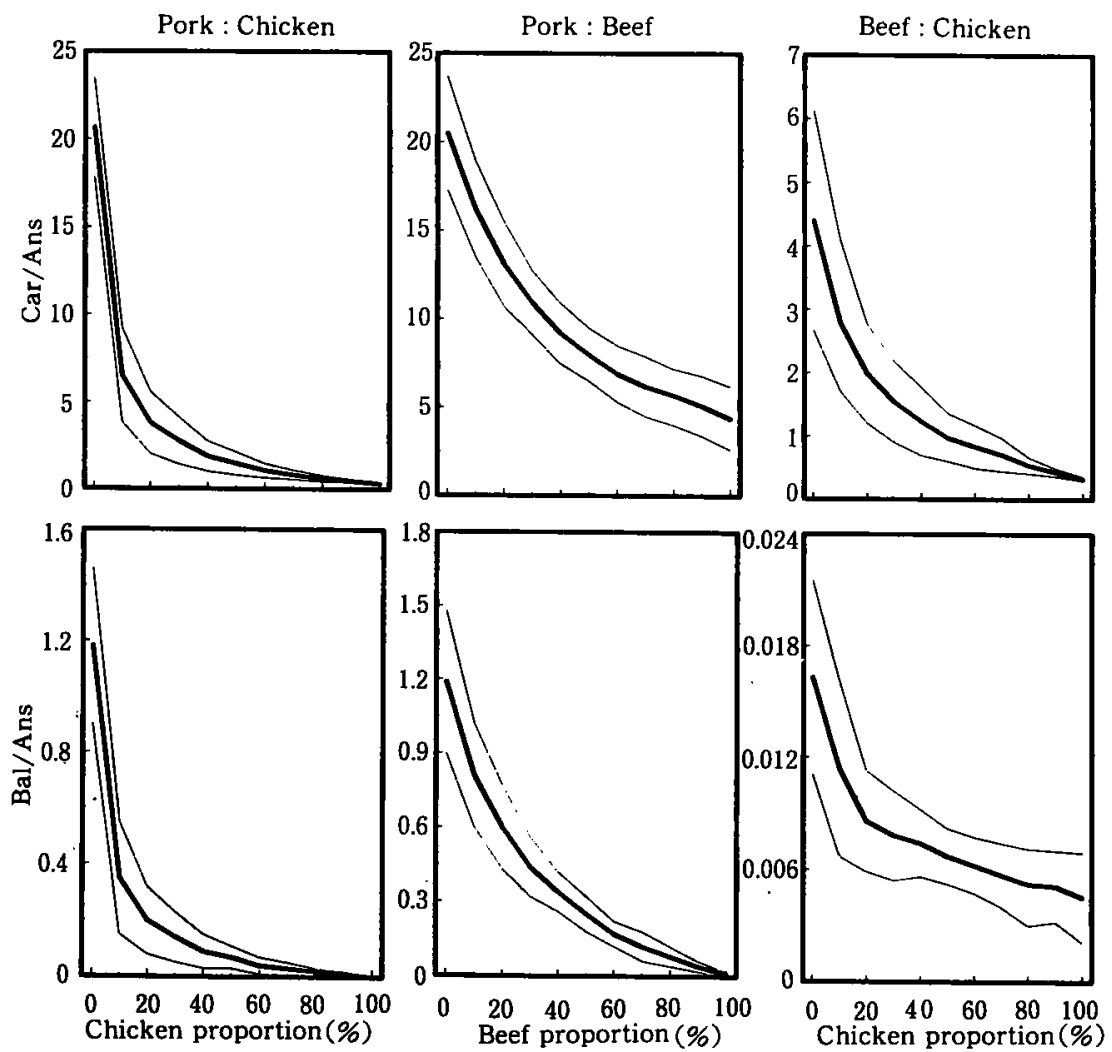

Fig. 1 Standard curves for calculating meat proportion in processed meat products made from two meat species from any two of beef, pork, and chicken

Thick line represents the average value from 8 to 16 determinations, and the thin line represents the standard deviation. 
Table 4 Estimation of chicken proportion in the processed meat products made from pork and chicken

\begin{tabular}{|c|c|c|c|c|c|c|}
\hline \multirow[t]{2}{*}{ No. } & \multirow{2}{*}{$\begin{array}{c}\text { Meat } \\
\text { products }\end{array}$} & \multicolumn{3}{|c|}{ Contents $(\mu \mathrm{mol} / g$ wet $w \mathrm{t})}$. & \multicolumn{2}{|c|}{ Dipeptide ratio } \\
\hline & & Car & Ans & $\mathrm{Bal}$ & Car/Ans & Bal/Ans \\
\hline 1. & Wiener A & 12.2 & 1.78 & 0.735 & $6.85(11 \sim 17)$ & $0.412(7 \sim 17)$ \\
\hline 2. & $\mathrm{~B}$ & 3.2 & 4.65 & 0.076 & $0.69(54 \sim 87)$ & $0.016(55 \sim 89)$ \\
\hline 3. & $\mathrm{C}$ & 3.5 & 7.42 & 0.064 & $0.47(77 \sim 96)$ & $0.009(79 \sim 100)$ \\
\hline 4. & $\mathrm{D}$ & 4.8 & 9.64 & 0.133 & $0.50(75 \sim 95)$ & $0.014(66 \sim 95)$ \\
\hline 5. & $\mathrm{E}$ & 4.5 & 6.46 & 0.198 & $0.70(57 \sim 86)$ & $0.031(40 \sim 80)$ \\
\hline 6. & Retort hamburg & 3.0 & 7.28 & 0.054 & $0.41(82 \sim 98)$ & $0.007(86 \sim 100)$ \\
\hline 7. & Shao-mai & 1.0 & 0.89 & 0.044 & $1.12(36 \sim 70)$ & $0.049(30 \sim 70)$ \\
\hline
\end{tabular}

Chicken meat proportions (\%) were estimated from the dipeptide ratios and the standard curves in Fig.

1 and are shown in parentheses.

Table 5 Estimation of beef proportion in the processed meat products made from pork and beef

\begin{tabular}{|c|c|c|c|c|c|c|}
\hline \multirow[t]{2}{*}{ No. } & \multirow{2}{*}{$\begin{array}{c}\text { Meat } \\
\text { products }\end{array}$} & \multicolumn{3}{|c|}{ Contents $(\mu \mathrm{mol} / \mathrm{g}$ wet $\mathrm{wt})}$. & \multicolumn{2}{|c|}{ Dipeptide ratio } \\
\hline & & Car & Ans & Bal & Car/Ans & Bal./Ans \\
\hline 1. & Wiener A & 9.2 & 0.89 & 2.23 & $10.3(22 \sim 45)$ & $2.49(-)$ \\
\hline 2. & B & 8.2 & 1.09 & 0.385 & $7.5(40 \sim 76)$ & $0.354(30 \sim 55)$ \\
\hline 3. & $\mathrm{C}$ & 9.4 & 1.51 & 0.359 & $6.2(52 \sim 98)$ & $0.239(43 \sim 59)$ \\
\hline 4. & $\mathrm{D}$ & 4.8 & 0.73 & 0.106 & $6.6(48 \sim 92)$ & $0.146(54 \sim 75)$ \\
\hline 5. & $\mathrm{E}$ & 15.6 & 1.39 & 0.536 & $11.2(18 \sim 39)$ & $0.385(24 \sim 44)$ \\
\hline 6. & $\mathrm{~F}$ & 19.8 & 1.68 & 0.665 & $11.8(16 \sim 35)$ & $0.396(22 \sim 42)$ \\
\hline 7. & Canned wiener A & 4.4 & 2.19 & 0.086 & $2.0(-)$ & $0.039(78 \sim 95)$ \\
\hline 8. & B & 4.4 & 2.53 & 0.172 & $1.7(-)$ & $0.068(69 \sim 89)$ \\
\hline 9. & Frankfurter & 8.4 & 0.41 & 0.404 & $20.5(0 \sim 10)$ & $0.974(0 \sim 12)$ \\
\hline 10. & Retort hamburg & 6.1 & 0.27 & 0.214 & $22.6(0 \sim 5)$ & $0.794(2 \sim 12)$ \\
\hline
\end{tabular}

Beef proportions (\%) were estimated from the dipeptide ratios and the standard curves in Fig. 1 and are shown in parentheses.

almost in agreement with the expected values (Table 2) except for several products such as Nos. 1, 7, and 8. It was impossible to determine the beef proportion in sample No. 1 which showed a much higher balenine/anserine ratio than its range in only pork. Canned wiener sausages, Nos. 7 and 8 , on the other hand, showed a lower carosine/anserine ratio than beef, though the balenine/anserine ratio suggested a high proportion of beef. In these sausages, it is probable to be adulterated chicken meat or visceral muscle of cattle or pig.

Very close estimations from both ratios were obtained in the other beef and pork proportions such as Nos. 5, 6, 9, and 10. Products with a low pork proportion such as Nos. 2-4, however, showed rather broad and different proportions estimated from the two ratios, because of the large standard deviations of the carnosine/anserine ratio within the high beef proportion in the standard curve shown in Fig. 1. The indication of " $55 \%$ beef" on the label in No. 2 product almost coincided with the estimated beef proportion of $40-55 \%$ obtained from the overlapped range between the two estimated ranges, $40-76 \%$ from the carnosine/ anserine ratio and $30-55 \%$ from the balenine/ anserine ratio. Thus, the meat proportion may be estimated more precisely when the overlapped value obtained from the carnosine/ anserine and balenine/anserine ratios is compared.

Meat products containing beef and chicken were not able to be analyzed in the present 
experiment, since it was expected to give almost similar results to the other combinations shown above. Many techniques have been developed to discriminate meat origin in uncooked meat and heat processed meat products. Most of the methods, however, were developed for the detection of meat adulteration qualitatively. The semi-quantitative determination of meat species in heat processed products has not yet been successful except for enzyme-linked immunosorbent assays ${ }^{1)}$ and the DNA hybridization method ${ }^{7)}$. As proposed by CARNEGIE et al. ${ }^{12)}$, it was confirmed by the present experiments that the histidine dipeptide analysis was a simple and fast method for the semi-quantitative discrimination of meat species.

Judging from the above data, this method may lead to a wrong conclusion when the product contains meat extract or non-skeletal muscle and contains only a small amount of meat or small amount of adulteration of other meats. The method may also be useless for products made from more than three meat species. In spite of these disadvantages, the proposed method has some advantages as follows :(1) easy sample preparation with no special reagent, (2) high-sensitivity for detection, especially for balenine, (3) fast ( $25 \mathrm{~min}$ ) and simple isocratic HPLC, (4) no necessity for the determination of the other components such as moisture content, (5) substantially independent of the ingredients contained in the products, (6) stability of these compounds even in cooked meat, and (7) availability of two different complementary factors, the carnosine/anserine and balenine/anserine ratios. In order to more precisely estimate the meat proportion in mixed meat products, further determination of these dipeptide ratios would be needed on large populations and various muscle samples of each animal.

Acknowledgement : The present study was supported in part by a grant from the Ito Memorial Foundation. The authors are indebted to a Masako Murakoshi and Chiharu W ATANABE for their technical assistance.

\section{References}

1) HitchCOCK, C.H.S. and CRIMES, A.A. : Biochemical Identification of Meat Species, Patterson, R.L.S. ed. (Elsevier Appl. Sci. Publ,, New York), p.1 (1985).

2) Kitada, Y., Tomita, S., Shimada, Y., Ikeda, Y. and SHoKawa, T.: Nippon Shokuhin Kogyo Gakkaishi, 37, 383 (1990).

3) Janssen, F.W., Hagele, G.H., Voorpostel, A.M. B. and BAAIJ, J.A. : J. Food Sci., 55, 1528 (1990).

4) MCCORMICK, R.J., CoLLINS, D.A., FIELD, R.A. and MOORE, T.D. : J. Food Sci., 57, 516 (1992).

5) Baral, B.K., NAYAK, R.R., Singhal, R.S. and Kulkarni, P.R. : Trends Food Sci. Technol, 3, 69 (1992).

6) Chikuni, K., Ozutsumi, K., Koishikawa, T. and Kato, S. : Meat Sci., 27, 119 (1990).

7) EввенфJ, K.F. and Thомsen, P.D. : Meat Sci., 30, 221 (1991).

8) EввенфJ, K.F. and Thомsen, P.D. : Meat Sci., 30, 359 (1991).

9) Chikuni, K., Tabata, T., Kosugiyama, M., Monma, M. and Saito, M. : Meat Sci., 37, 337 (1994).

10) Tinbergen, B.J. and Slump, P.:Z. Lebensm. Unters. -Forsch., 161, 7 (1976).

11) Carnegie, P.R., Hee, K.P. and Bell, A.W. : J. Sci. Food Agric., 33, 795 (1982).

12) CARnegie, P.R., Collins, M.G. and ILic, M.Z. : Meat Sci., 10, 145 (1984).

13) CARnegie, P.R., ILic, M.Z., Etheridge, M.O. and StUART, S. : Australian Vet. J., 62, 272 (1985).

14) Plowman, J.E. and Close, E.A. : J. Sci. Food Agric., 45, 69 (1988).

15) Авe, H. and Ohmama, S. : Comp. Biochem. Physiol., 88B, 507 (1987).

(Received Oct. 27, 1994)

\section{ヒスチジン関連ジペプチド比による食肉加工製品中の} 肉種の判別

\section{阿部宏喜* · 大能恵美子* \\ *共立女子大学家政学部食物学科 \\ （テ193 東京都八王子市元八王子町 1-710）}

高速液体クロマトグラフィによりヒスチジン関連ジペ プチド。すなわちカルノシン，アンセリンおよびバレニ ンを分析し，食肉加工製品中の肉種の判別の可能性を検 
討した. 牛, 豚, 馬, 鹿, 鶏怙よび七面鳥肉におけるこ れらジペプチドの分布およびジペプチドの比率，すなわ ちカルノシン/アンセリンおよびバレニン/アンセリンは 種特異的であった。これらの比率加ら，牛，豚あるいは 鷄肉を単独で用いたほとんどの食肉加工製品の肉種の判 別が可能であった．水分，脂質含量あるいはその他の添
加物は肉種の判別に影響を与えなかった。 また，これら の肉の内，二種を混合した食肉加工製品については，混 合比率とジペプチド比の検量線を用いることにより，ほ とんどの製品で半定量的に肉種を判別することが可能で あった。 